\title{
The Methods to Crystallize Anhydrous L-Phenylalanine from Methanol-Water Solution
}

\author{
Xiaoxue Cao ${ }^{1}$, Shaochang $\mathrm{Ji}^{2}$, Yumei Ben ${ }^{3}$, Wenjie Kuang ${ }^{1}$, Anping Liao ${ }^{1}$, Ping Lan ${ }^{1}$ and \\ Jinyan Zhang ${ }^{1, *}$ \\ 1 Guangxi Key Laboratory for Polysaccharide Materials and Modifications, Key Laboratory of Chemical and \\ Biological Transformation Process of Guangxi Higher Education Institutes, School of Chemistry and \\ Chemical Engineering, Guangxi University for Nationalities, Nanning 530006, China; \\ cxx818221@163.com (X.C.); kwj1245@163.com (W.K.); zjy_003@126.com (A.L.); gxLanping@163.com (P.L.) \\ 2 Guangxi Tobacco Monopoly Bureau, Nanning 530006, China; jisc2008@126.com \\ 3 Shengtong Technology and Development Company, Tianjin 300000, China; 15202277408@163.com \\ * Correspondence: zjy_03@126.com; Tel.: +86-189-7882-1061
}

Received: 11 November 2019; Accepted: 3 January 2020; Published: 22 January 2020

\begin{abstract}
In this paper, the transformation water activity of L-Phenylalanine (L-Phe) in a methanol-water solution at a different temperature was measured by the ternary diagram. The influence of water activity on the transformation temperature and on the transformation rate was investigated. The solubility of the metastable form of different water activities was estimated based on the thermodynamic equilibrium and the results showed that the anhydrous L-Phe can be synthesized at room temperature by decreasing water activity, the transformation rate from monohydrate to anhydrate was enhanced with the increase of water activity. The predicted solubility value is in good agreement with the experimentally obtained. Meanwhile, tailor-made additives were applied into the system as to investigate the transformation behavior of L-Phe. Their mechanism was proposed based on the Langmuir model fitting. The result manifested that the addition of L-Trp/L-His amino acid in the L-Phe solution decelerated the transformation rate. When the concentration of L-Trp amino acid reached $0.7 \times 10^{-4} \mathrm{~mol} / \mathrm{mL}$, the transformation behavior of L-Phe can be fully impeded, and the transformation behavior can be partially inhibited with the addition of L-Trp at $313.15 \mathrm{~K}$ or with the addition of L-His at $283.15 \mathrm{~K} / 313.15 \mathrm{~K}$.
\end{abstract}

Keywords: L-Phenylalanine; solubility; water activity; ternary phase diagram; transformation behavior

\section{Introduction}

Hydrate is an ordinary pharmaceutical polymorph [1-3], 57\% of pharmaceuticals can form hydrate polymorphs. Different polymorphs may present different properties, such as solubility, physical, bioavailability and product performance [4-8]. It is of great significance to understand and control the transformation behavior during pharmaceutical development and manufacturing processes $[9,10]$. Recently, much attention has been focused on the regulation of polymorphism and various methods have been used to control the polymorphism crystal form, such as temperature, additives and the time of crystal transformation. Now, the method of regulating water activity to realize production control of hydrated polymorphism due to low contaminate is put forward in this paper. Recently, much attention has been focused on the regulation of polymorphism and various methods have been used to control transformation, such as temperature, additives and solvents. Now, the method of regulating water activity to realize the production control of hydrated polymorphism due to low contaminate is put forward in this paper. 
In the present work, L-Phenylalanine (L-Phe, $\mathrm{C}_{38} \mathrm{H}_{72} \mathrm{~N}_{2} \mathrm{O}_{12}$ ) (Figure 1) was chosen as a model system which exits in an anhydrous form and as a monohydrate form [11]. L-Phe is one of the nine essential amino acids and an important intermediate in the synthesis of many biological and chemical substances [12-14], widely used in the pharmaceutical, chemical and food industries [15-18]. Commonly, the anhydrous form was the target crystal form on account of its flaky habit, good fluidity, easy storage and transportation and its ability to be crystallized from the solution above $37{ }^{\circ} \mathrm{C}$. The transformation behavior of L-Phe was discussed by Mohan [19] and Wang [20], and our preliminary work using amino-acids as a tailor-made additive was presented in [21]. Nevertheless, water activity was never applied in the solution to investigate the transformation behavior.

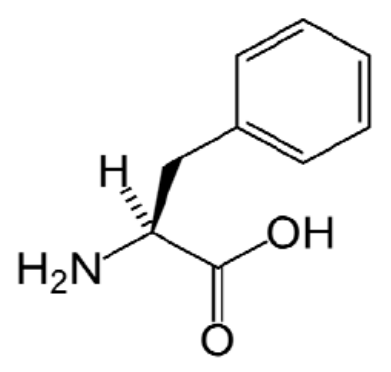

Figure 1. L-Phe structure.

The target of this research is to obtain L-Phe anhydrate from solution by altering the water activity of the system. The transformation water activity in a methanol-water solution at different temperatures was determined by phase equilibrium, the influence of water activity on transformation (temperature, transformation rate) was investigated. Based on thermodynamic equilibrium, transformation water activity was calculated by using the solubility ratio of hydrate to anhydrate. Besides these, another regulation method-additives was applied in the system. The tailor-made additive has the same molecular structure as the parent molecule, but with a slight change in structure, which is easy to selectively interact with the active component. It has been proved to be an effective method to control solution crystallization kinetics. So the effect and mechanism of additives on the transformation behavior was discussed. All the results can provide a theoretical basis for the regulated transformation of hydrated polymorphs.

\section{Materials and Methods}

\subsection{Materials}

L-Phe was obtained from Maclean Biochemical Technology Co., Ltd (Shanghai, China). Methanol was supplied by Guangfu Chemical Co., Ltd (Tianjin, China). A chromatographic methanol class was obtained from Merck \& Co., Inc. They were used as received.

\subsection{Solubility Measurement}

Several solubility determination methods have been summarized in [22]. In this work, the solubility of L-Phe was determined by a static method. The saturated solution was obtained by adding excessive L-Phe in glass vessels containing solvents. Once the solid-liquid equilibrium was arrived, the agitation was stopped, the upper solution was filtered by $0.22 \mu \mathrm{m}$ filters and analyzed by HPLC (1200 Series, Agilent1200, New York, NY, USA). The remaining solid was separated and characterized by PXRD (Rigaku) D/max-2500).

The mole fraction solubility of L-Phe in binary solvent mixtures was calculated on the basis of the following equation:

$$
x=\frac{m_{1} / M_{1}}{m_{1} / M_{1}+m_{2} / M_{2}+m_{3} / M_{3}}
$$


where, $x$ represents mole fraction solubility of L-Phe in binary solvent mixtures; $m_{1}, m_{2}$, and $m_{3}$ represent the masses of L-Phe, organic solvent and water in the binary solvent mixtures; $M_{1}, M_{2}$ and $M_{3}$ are the molecular weights of L-Phe, organic solvent and water in solvents.

\subsection{Transition Water Activity Measurement}

Excessive L-Phe was added to the water/methanol mixtures. (varying water mole fraction from 0.10 to 0.99 ), and water activity was assigned using the Wilson equation. Parameters of the Wilson equation for above solvents are listed in Section 3.2.

\subsection{Transformation Controlled by Tailor-Made Additives}

All transformation experiments were conducted using the method reported in the literature [23]. The saturated solution of L-Phe ${ }_{+} \mathrm{H}_{2} \mathrm{O} / \mathrm{L}-\mathrm{Phe}$ was prepared by dissolving excessive L-Phe ${ }_{+} \mathrm{H}_{2} \mathrm{O}$ or L-Phe in water or with a different concentration of L-Trp/L-His acid at the fixed temperature for $24 \mathrm{~h}$. After that, the solution was filtered. A $40 \mathrm{~g}$ portion of the saturated solution of L-Phe ${ }_{+} \mathrm{H}_{2} \mathrm{O} / \mathrm{L}-\mathrm{Phe}$ with L-Phe/L-Phe $+\mathrm{H}_{2} \mathrm{O}$ powder $(0.2 \mathrm{~g})$ was employed in each experiment. The transformation was implemented in different water activity with continuous agitation. The temperature was kept at 283.15 K for transformation from L-Phe to L-Phe ${ }_{+} \mathrm{H}_{2} \mathrm{O}$ and at $323.15 \mathrm{~K}$ for transformation from L-Phe $+\mathrm{H}_{2} \mathrm{O}$ to L-Phe. Samples were taken out and filtered at the desired time intervals. The solid was dried at $303.5 \mathrm{~K}$ for $24 \mathrm{~h}$ and the transformation degree was analyzed by PXRD.

\subsection{Methods of Analysis}

X-ray diffraction: Minflex600 Rigaku was used to collect PXRD data of all samples. Cu K $\alpha$ radiation was used as a source with wavelength $\lambda=1.5406 \AA$ at $15 \mathrm{~mA}$ and $40 \mathrm{kV}$. All samples were scanned at $2 \theta$ range from $3^{\circ}$ to $40^{\circ}$ at a scanning rate of $1^{\circ} \mathrm{min}^{-1}$.

Differential scanning calorimetry: The melting temperature of L-Phe was determined by differential scanning calorimetry (DSC) (Mettler-Toledo, model DSC1/500, Switzerland) under a nitrogen atmosphere. Temperature ranged from $293.15 \mathrm{~K}$ to $1093.15 \mathrm{~K}$, heating rate $10 \mathrm{~K} / \mathrm{min}$, the sample quantity was $9 \mathrm{mg}$.

The concentration of L-Phe was quantified by high performance liquid chromatography (1200 Series, Agilent1200, New York, NY, USA) at $260 \mathrm{~nm}$, using a ZORBAX SB-C18 column $(4.6 \mathrm{~mm} \times 150$ $\mathrm{mm}, 5$-micron, Agilent, China). The mobile phase was $30 \%$ methanol $\left(V_{\text {methanol }}: V_{\text {water }}=3: 7\right)$ with a flow rate of $1 \mathrm{~mL} / \mathrm{min}$.

\section{Thermodynamic and Correlating Models}

\subsection{Correlation of Solubility with Temperature}

The mole fraction solubility of L-Phe $(x)$ with temperature $(T)$ was fitted by the modified Apelblat [24-27] and $\lambda h$ Equation (3) [28], described by Equations (2) and (3).

$$
\begin{aligned}
\ln x & =A+\frac{B}{T / K}+C \ln (T / K) \\
\frac{1}{x}-1 & =\frac{1}{\lambda}\left\{\exp \left[\lambda h\left(\frac{1}{T}-\frac{1}{T_{m}}\right)-1\right]\right\}
\end{aligned}
$$

where $T_{m}$ stands for the melting point of L-Phe; $A, B, C, \lambda$ and $h$ are the model parameters.

The models were evaluated by the relative average deviation (ARD) and root-mean-square deviation (RMSD) $[29,30]$ which can be expressed by the following equation:

$$
R M S D=\left[\frac{1}{N} \sum_{i=1}^{N}\left(x^{c}-x^{e}\right)^{2}\right]^{1 / 2}
$$




$$
R A D=\frac{1}{N} \sum\left(\frac{\left|x^{\mathcal{c}}-x^{e}\right|}{x^{e}}\right)
$$

where $N$ stands for the number of experimental points $x^{e}$ and $x^{\mathcal{C}}$ represents the experiment solubility and calculated ones.

\subsection{Correlation of Water Activity}

The relationship between water activity $a\left[\mathrm{H}_{2} \mathrm{O}\right]$ and the water mole fraction was reported in Rs [31], which is shown in Equation (6):

$$
a\left[H_{2} \mathrm{O}\right]=\gamma_{1} x_{1}
$$

where $a\left[\mathrm{H}_{2} \mathrm{O}\right]$ stands for the water activity; and $x_{1}$ stands for the water mole fraction in solvent mixtures; the $\gamma_{1}$ represents the activity coefficient of water in methanol-water

The relationship between transition water activity $a_{T}\left[\mathrm{H}_{2} \mathrm{O}\right]$ and the water activity $a\left[\mathrm{H}_{2} \mathrm{O}\right]$ was reported in Rs10 by Equation (7):

$$
a_{T}\left[\mathrm{H}_{2} \mathrm{O}\right]=\sqrt[m]{\frac{[A] x_{h}}{[A] x_{a}}} \times a\left[\mathrm{H}_{2} \mathrm{O}\right]
$$

where $x_{h}[A]$ and $x_{a}[A]$ stand for hydrate solubility and anhydrate solubility in the solvent. $a\left[\mathrm{H}_{2} \mathrm{O}\right]$ is the water activation for the binary system, $a_{T}\left[\mathrm{H}_{2} \mathrm{O}\right]$ is the transition water activity, which is the water activation for the binary system when the crystals transform from one crystal to another.

The activity coefficient in methanol-water was calculated by the Wilson [32] equation, which described in Equations (8)-(12):

$$
\begin{gathered}
\frac{g^{\mathrm{E}}}{R T}=-x_{1} \ln \left(x_{1}+\wedge_{12} x_{2}\right)-x_{2}+\wedge_{21} x_{1} \\
\ln \gamma_{1}=-\ln \left(x_{1}+\wedge_{12} x_{2}\right)+x_{2}\left(\frac{\wedge_{12}}{x_{1}+\wedge_{12} x_{2}}-\frac{\wedge_{21}}{x_{2}+\wedge_{21} x_{1}}\right) \\
\ln \gamma_{2}=-\ln \left(x_{2}+\wedge_{21} x_{1}\right)+x_{1}\left(\frac{\wedge_{21}}{x_{2}+\wedge_{21} x_{1}}-\frac{\wedge_{12}}{x_{1}+\wedge_{12} x_{2}}\right) \\
\wedge_{21}=\frac{V_{1}^{\mathrm{L}}}{V_{2}^{\mathrm{L}}} \exp \left[-\left(g_{21}-g_{22}\right) / R T\right] \\
\wedge_{12}=\frac{V_{2}^{\mathrm{L}}}{V_{1}^{\mathrm{L}}} \exp \left[-\left(g_{12}-g_{11}\right) / R T\right]
\end{gathered}
$$

where $V_{1}^{\mathrm{L}}$ and $V_{2}^{\mathrm{L}}$ represents the molar volume of water and methanol, respectively ( $V_{1}^{\mathrm{L}}$ equal to 18.018883; $V_{2}^{\mathrm{L}}$ equal to 39.57286 ), $g_{12}-g_{11}$ and $g_{21}-g_{22}$ can be obtained through the gas-liquid balance manual ( $g_{12}-g_{11}$ equal to 107.3832; $g_{21}-g_{22}$ equal to 469.5509 [33]), $x_{1}$ is the mole fraction of water in the solvent mixtures, $x_{2}$ is the mole fraction of organic in the solvent mixtures, $\gamma_{1}$ represents the activity coefficient of water in methanol-water and $\gamma_{2}$ represents the activity coefficient of organic in methanol-water, $\hat{}_{12}$ and $\hat{~}_{21}$ are the adjustable parameters for the Wilson equation. 


\subsection{Transformation Model}

Davey and Mullin derived the following expression for the step velocity in the presence of impurity, assuming that the rate of surface diffusion of growth units to the steps, which is a rate-determining process, is reduced by impurities adsorbed on the terraces [34-36]:

$$
\begin{gathered}
v / v_{0}=1-e \theta_{e q} \\
v / v_{0}=1-[e K c /(1+K c)]
\end{gathered}
$$

where $v_{0}$ is the step velocity without impurity; e stands for an effectiveness factor; $K$ stands for the Langmuir constant; $\theta_{e q}$ represents an adsorption factor.

$v / v_{0}$ in Equation (4) can be substituted by the relative growth rate $G / G_{0}$ provided that $G$ is supposed to be proportionate to the $v$.

$$
G / G_{0}=1-[e K c /(1+K c)]
$$

Meanwhile, $G$ is in inverse proportion to the transition time $t$. Thus, the equation can be rewritten as follows:

$$
t_{0} / t=1-[e K c /(1+K c)]
$$

where, $t_{0}$ is the transition time without impurity.

\section{Results and Discussion}

\subsection{Solubility in the Binary Solvent Mixtures}

The solubility of L-Phe in binary solvent mixtures of (water-methanol) at the temperature ranging from $293.15 \mathrm{~K}$ to $322.15 \mathrm{~K}$ was measured and presented in Table 1 . The results demonstrated that L-Phe anhydrate solubility was increased with temperature, but the increase was not large, which indicated that the solubility of L-Phe was not sensitive to temperature. At a certain temperature, the solubility increased with the water activity due to the solvent polarity increasing with the water activity.

The solubility data calculated by the modified Apelblat equation and $\lambda$ h equation were graphically shown in Figure 2, and the model parameters, ARD and RMSD values were all listed in Table 2. It can be seen that ARD and RMSD were acceptable, all no greater than 0.030 and $7.45 \times 10^{-5}$.
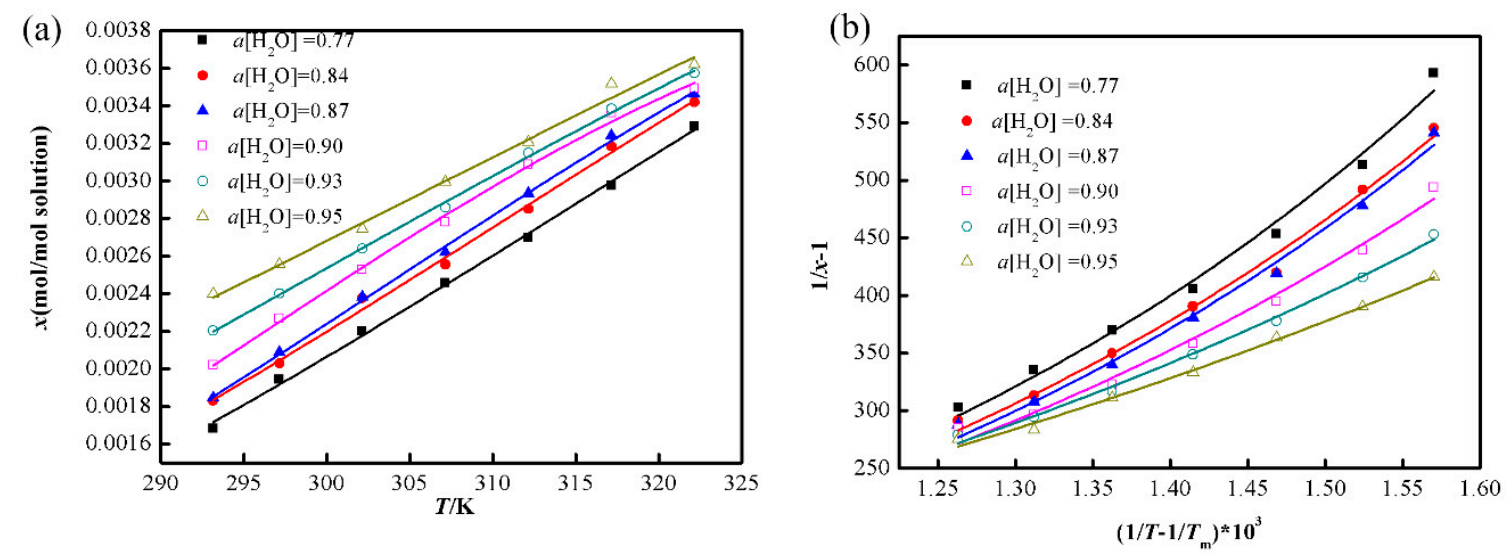

Figure 2. Mole fraction of L-Phe in methanol-water solvent mixtures calculated by Apelblat equation (a) and $\lambda$ h equation $(\mathbf{b})$. 
Table 1. Experimental solubility $\left(10^{3} \mathrm{x}\right)$ of L-Phe in methanol-water solvent mixtures with different water activities.

\begin{tabular}{|c|c|c|c|c|c|c|c|c|c|c|c|}
\hline $\mathrm{T} / \mathrm{K}$ & $x^{\exp }$ & $x^{\text {cal,Apel }}$ & $\mathrm{x}^{\mathrm{cal}, \lambda \mathrm{h}}$ & $\mathrm{T} / \mathrm{K}$ & $x^{\exp }$ & $x^{\text {cal,Apel }}$ & $\mathrm{x}^{\mathrm{cal}, \lambda \mathrm{h}}$ & $x^{\exp }$ & $x^{\text {cal,Apel }}$ & $\mathrm{x}^{\mathrm{cal}, \lambda \mathrm{h}}$ & $x^{\exp }$ \\
\hline \multicolumn{4}{|c|}{$a\left[\mathrm{H}_{2} \mathrm{O}\right]=0.77$} & \multicolumn{4}{|c|}{$a\left[\mathrm{H}_{2} \mathrm{O}\right]=0.90$} & \multicolumn{4}{|c|}{$a\left[\mathrm{H}_{2} \mathrm{O}\right]=0$} \\
\hline 322.15 & 3.29 & 3.27 & 3.37 & 322.15 & 3.49 & 3.52 & 3.67 & 322.15 & 0.947 & 3.52 & 3.67 \\
\hline 317.15 & 2.97 & 3.00 & 3.02 & 317.15 & 3.36 & 3.32 & 3.34 & 317.15 & 0.841 & 3.32 & 3.34 \\
\hline 312.15 & 2.70 & 2.72 & 2.71 & 312.15 & 3.09 & 3.08 & 3.03 & 312.15 & 0.760 & 3.08 & 3.03 \\
\hline 307.15 & 2.46 & 2.45 & 2.42 & 307.15 & 2.78 & 2.82 & 2.75 & 307.15 & 0.693 & 2.82 & 2.75 \\
\hline 302.15 & 2.20 & 2.18 & 2.15 & 302.15 & 2.53 & 2.54 & 2.49 & 302.15 & 0.579 & 2.54 & 2.49 \\
\hline 297.15 & 1.94 & 1.92 & 1.91 & 297.15 & 2.27 & 2.25 & 2.24 & 297.15 & 0.515 & 2.25 & 2.24 \\
\hline 293.15 & 1.68 & 1.72 & 1.73 & 293.15 & 2.02 & 2.02 & 2.06 & 293.15 & 0.423 & 2.02 & 2.06 \\
\hline \multicolumn{4}{|c|}{$a\left[\mathrm{H}_{2} \mathrm{O}\right]=0.84$} & \multicolumn{4}{|c|}{$a\left[\mathrm{H}_{2} \mathrm{O}\right]=0.93$} & \multicolumn{4}{|c|}{$a\left[\mathrm{H}_{2} \mathrm{O}\right]=1$} \\
\hline 322.15 & 3.42 & 3.43 & 3.52 & 322.15 & 3.57 & 3.59 & 3.66 & 322.15 & 3.79 & 3.59 & 3.66 \\
\hline 317.15 & 3.18 & 3.15 & 3.17 & 317.15 & 3.38 & 3.36 & 3.38 & 317.15 & 3.68 & 3.36 & 3.38 \\
\hline 312.15 & 2.85 & 2.87 & 2.85 & 312.15 & 3.15 & 3.13 & 3.11 & 312.15 & 3.45 & 3.13 & 3.11 \\
\hline 307.15 & 2.55 & 2.59 & 2.56 & 307.15 & 2.86 & 2.89 & 2.85 & 307.15 & 3.21 & 2.89 & 2.85 \\
\hline 302.15 & 2.38 & 2.32 & 2.29 & 302.15 & 2.64 & 2.64 & 2.62 & 302.15 & 3.07 & 2.64 & 2.62 \\
\hline 297.15 & 2.03 & 2.05 & 2.04 & 297.15 & 2.40 & 2.40 & 2.39 & 297.15 & 2.76 & 2.40 & 2.39 \\
\hline \multirow[t]{2}{*}{293.15} & 1.83 & 1.84 & 1.85 & 293.15 & 2.20 & 2.20 & 2.23 & 293.15 & 2.57 & 2.20 & 2.23 \\
\hline & \multicolumn{3}{|c|}{$a\left[\mathrm{H}_{2} \mathrm{O}\right]=0.87$} & \multicolumn{4}{|c|}{$a\left[\mathrm{H}_{2} \mathrm{O}\right]=0.95$} & & & & \\
\hline 322.15 & 3.46 & 3.47 & 3.60 & 322.15 & 3.62 & 3.66 & 3.70 & & & & \\
\hline 317.15 & 3.24 & 3.21 & 3.24 & 317.15 & 3.52 & 3.44 & 3.45 & & & & \\
\hline 312.15 & 2.93 & 2.94 & 2.91 & 312.15 & 3.21 & 3.22 & 3.20 & & & & \\
\hline 307.15 & 2.62 & 2.65 & 2.60 & 307.15 & 2.99 & 3.00 & 2.98 & & & & \\
\hline 302.15 & 2.38 & 2.36 & 2.32 & 302.15 & 2.74 & 2.78 & 2.76 & & & & \\
\hline 297.15 & 2.09 & 2.08 & 2.07 & 297.15 & 2.56 & 2.55 & 2.56 & & & & \\
\hline 293.15 & 1.84 & 1.85 & 1.88 & 293.15 & 2.40 & 2.38 & 2.40 & & & & \\
\hline
\end{tabular}

$\mathrm{x}^{\mathrm{exp}}$ represents the solubility mole fraction determined by the test; $\mathrm{x}^{\mathrm{cal}, \mathrm{Apel}}$ represents the solubility mole fraction calculated by the Apelblat equation; $\mathrm{x}^{\mathrm{cal}, \lambda \mathrm{h}}$ represents the solubility mole fraction calculated by the $\lambda \mathrm{h}$ equation.

Table 2. Regressed parameters $A R D$ and $R M S D$ for L-Phe in different water activities by Apelblat and $\lambda$ h Equation.

\begin{tabular}{cccccccccc}
\hline $\begin{array}{c}\text { Equation } \\
\text { Model }\end{array}$ & Parameter & $\mathbf{0}$ & $\mathbf{0 . 7 7}$ & $\mathbf{0 . 8 4}$ & $\mathbf{0 . 8 7}$ & $\mathbf{0 . 9 0}$ & $\mathbf{0 . 9 3}$ & $\mathbf{0 . 9 5}$ & $\mathbf{1}$ \\
\hline & $A$ & 322.8 & 169.60 & 178.46 & 246.33 & 315.16 & 149.99 & 80.57 & 223.12 \\
& $B$ & -17198.80 & -9805.76 & -10150.70 & -13260.89 & -16202.01 & -8473.50 & -5137.36 & -11537.24 \\
Apelblat & $C$ & -47.73 & -25.09 & -26.43 & -36.51 & -46.84 & -22.39 & -12.16 & -33.40 \\
& $R^{2}$ & 0.9928 & 0.9970 & 0.9949 & 0.9983 & 0.9926 & 0.9981 & 0.9903 & 0.9932 \\
& $A R D$ & 0.017 & 0.010 & 0.010 & 0.0062 & 0.0074 & 0.0045 & 0.0082 & 0.0071 \\
& $10^{5} R M S D$ & 1.19 & 3.49 & 1.67 & 2.63 & 1.86 & 3.15 & 2.37 & 2.85 \\
\hline & $\lambda$ & 0.025 & 0.042 & 0.038 & 0.041 & 0.028 & 0.018 & 0.012 & 0.010 \\
& $10^{-3} h$ & 103.04 & 48.74 & 50.96 & 48.55 & 60.38 & 78.15 & 96.40 & 100.32 \\
& $R^{2}$ & 0.9795 & 0.9889 & 0.9908 & 0.9913 & 0.9865 & 0.9950 & 0.9945 & 0.9783 \\
& $A R D$ & 0.015 & 0.018 & 0.013 & 0.015 & 0.019 & 0.0095 & 0.0080 & 0.030 \\
& $10^{5} R M S D$ & 2.55 & 4.85 & 5.22 & 5.88 & 7.45 & 4.02 & 4.15 \\
\hline
\end{tabular}

$R^{2}$ represents the solubility mole fraction determined by the test.

\subsection{The Ternary Phase Diagram}

The representative PXRD patterns of L-Phe in different water activities at a temperature $(293.15 \mathrm{~K}$, $297.15 \mathrm{~K}$ and $302.15 \mathrm{~K}$ ) were showed in Figure $3 \mathrm{~b}-\mathrm{d}$, and the mass fraction solubility data are listed in Table 3. The ternary phase diagrams (TPDS) for the system of methanol/water/L-Phe at different temperatures are presented in Figure 4. 
(a)
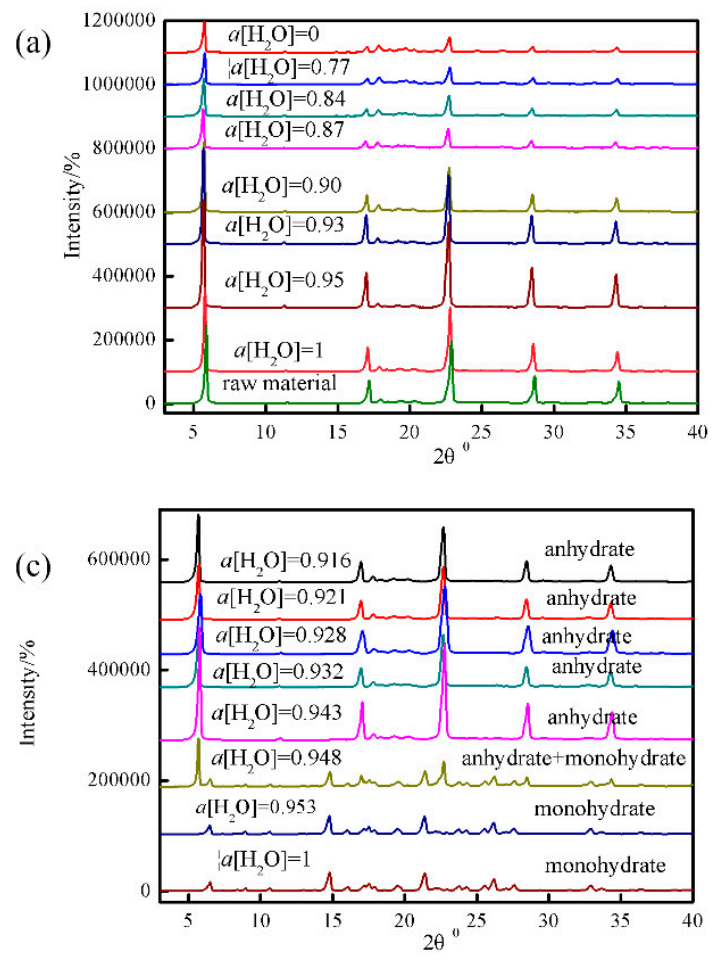

(b)

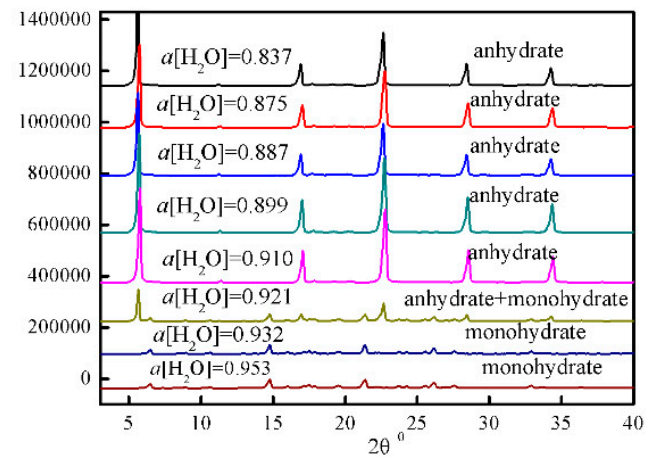

(d)

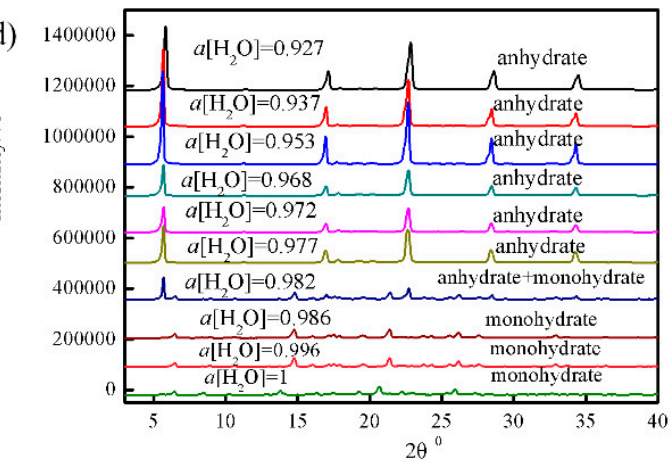

Figure 3. The XRD patterns of L-Phe in different water activities: (a) $293.15 \mathrm{~K}$, (b) $297.15 \mathrm{~K}$, (c) $302.15 \mathrm{~K}$ and (d) at equilibrium.

Table 3. Mass fraction solubility data of anhydrous or monohydrate L-Phe in a mixed solvent at temperatures $293.15 \mathrm{~K}, 297.15 \mathrm{~K}$ and $302.15 \mathrm{~K}$.

\begin{tabular}{ccccccccc}
\hline $\begin{array}{c}\text { Water } \\
\text { Activity }\end{array}$ & $\begin{array}{c}\text { Solubility } \\
\mathbf{1 0}^{\mathbf{3}} \boldsymbol{x}\end{array}$ & $\begin{array}{c}\text { Stable } \\
\text { Crystal }\end{array}$ & $\begin{array}{c}\text { Water } \\
\text { Activity }\end{array}$ & $\begin{array}{c}\text { Solubility } \\
\mathbf{1 0}^{\mathbf{3}} \boldsymbol{x}\end{array}$ & $\begin{array}{c}\text { Stable } \\
\text { Crystal }\end{array}$ & $\begin{array}{c}\text { Water } \\
\text { Activity }\end{array}$ & $\begin{array}{c}\text { Solubility } \\
\mathbf{1 0}^{\mathbf{3} \boldsymbol{x}}\end{array}$ & $\begin{array}{c}\text { Stable } \\
\text { Crystal }\end{array}$ \\
\hline \multirow{2}{293.15\mathrm{K}}{} & & & $297.15 \mathrm{~K}$ & & & $302.15 \mathrm{~K}$ & \\
0.837 & 1.89 & $\mathrm{~A}$ & 0.586 & 1.79 & $\mathrm{~A}$ & 0.837 & 2.38 & $\mathrm{~A}$ \\
0.875 & 2.03 & $\mathrm{~A}$ & 0.683 & 1.81 & $\mathrm{~A}$ & 0.869 & 2.38 & $\mathrm{~A}$ \\
0.887 & 2.07 & $\mathrm{~A}$ & 0.766 & 1.93 & $\mathrm{~A}$ & 0.899 & 2.53 & $\mathrm{~A}$ \\
0.899 & 2.11 & $\mathrm{~A}$ & 0.803 & 1.97 & $\mathrm{~A}$ & 0.927 & 2.64 & $\mathrm{~A}$ \\
0.910 & 2.16 & $\mathrm{~A}$ & 0.837 & 2.03 & $\mathrm{~A}$ & 0.937 & 2.67 & $\mathrm{~A}$ \\
0.921 & 2.27 & $\mathrm{~A}+\mathrm{M}$ & 0.869 & 2.08 & $\mathrm{~A}$ & 0.953 & 2.74 & $\mathrm{~A}$ \\
0.932 & 2.29 & $\mathrm{M}$ & 0.899 & 2.27 & $\mathrm{~A}$ & 0.968 & 2.83 & $\mathrm{~A}$ \\
0.953 & 2.40 & $\mathrm{M}$ & 0.905 & 2.30 & $\mathrm{~A}$ & 0.972 & 2.88 & $\mathrm{~A}$ \\
& & & 0.910 & 2.34 & $\mathrm{~A}$ & 0.977 & 2.92 & $\mathrm{~A}$ \\
& & & 0.916 & 2.36 & $\mathrm{~A}$ & 0.982 & 2.89 & $\mathrm{~A}+\mathrm{M}$ \\
& & & 0.921 & 2.38 & $\mathrm{~A}$ & 0.986 & 2.94 & $\mathrm{M}$ \\
& & & 0.927 & 2.40 & $\mathrm{~A}$ & 0.996 & 2.98 & $\mathrm{M}$ \\
& & & 0.932 & 2.47 & $\mathrm{~A}$ & 1 & 3.01 & $\mathrm{M}$ \\
& & & 0.943 & 2.50 & $\mathrm{~A}$ & & &
\end{tabular}

A represents L-Phe ${ }_{+} \mathrm{H}_{2} \mathrm{O}$ anhydrous and $\mathrm{M}$ represents L-Phe ${ }_{+} \mathrm{H}_{2} \mathrm{O}$ monohydrate at equilibrium. 
(a)

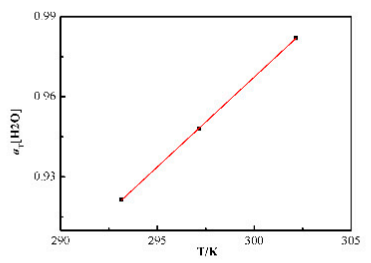

(c)

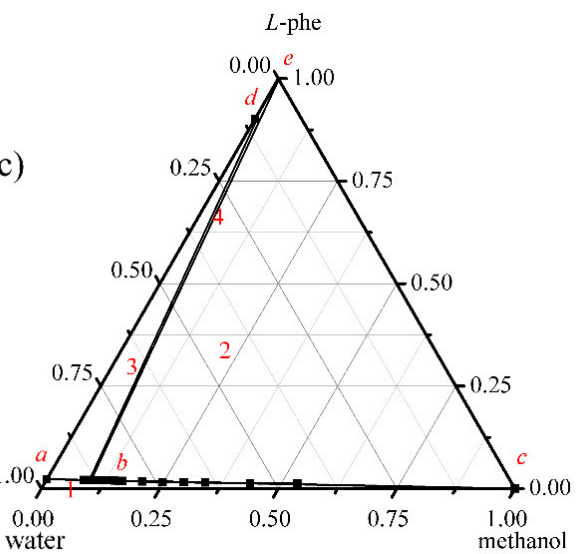

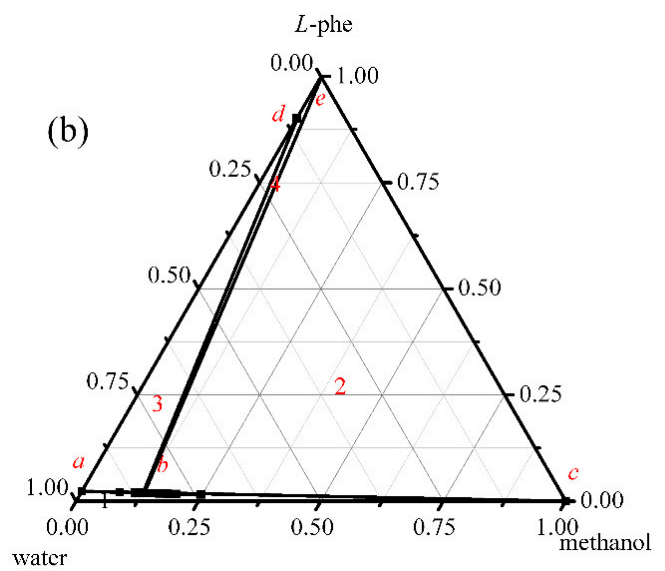

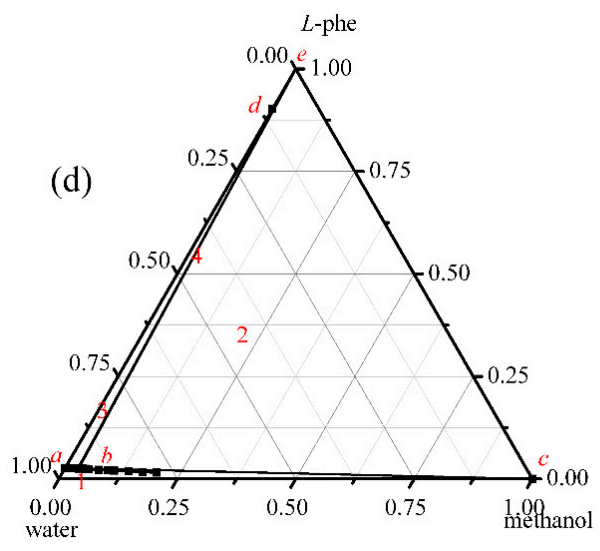

Figure 4. (a) Equilibrium water activity as a function of temperature; ternary phase diagram of methanol-L-Phe-water at temperature $293.15 \mathrm{~K}$ (b), $297.15 \mathrm{~K}$ (c) and (d) $307.15 \mathrm{~K}$.

As illustrated in Figure 4, it is divided into 4 regions by the solubility curves of L-Phe (line $\mathrm{b}-\mathrm{c}$ ) and L-Phe ${ }_{+} \mathrm{H}_{2} \mathrm{O}$ (line $\mathrm{a}-\mathrm{b}$ ). The point of intersection of these two solubility curves $\mathrm{b}$ is the transformation point, where anhydrous L-Phe and L-Phe ${ }_{+} \mathrm{H}_{2} \mathrm{O}$ can coexist at this point. Region 1 means the undersaturated solution. Region $2 / 3$ stands for the solution in equilibrium with anhydrous L-Phe and L-Phe ${ }_{+} \mathrm{H}_{2} \mathrm{O}$, respectively. Region 4 signifies the coexistence of anhydrous L-Phe and L-Phe ${ }_{+} \mathrm{H}_{2} \mathrm{OThe} \mathrm{L}-\mathrm{Phe}_{+} \mathrm{H}_{2} \mathrm{O}$ is the most stable form when water activity is higher than the transition water activity, i.e., Region 3, and anhydrous L-Phe is the stable form if the water activity is lower than the transition, i.e., Region 2. In other words, anhydrous L-Phe is stable when $a\left[\mathrm{H}_{2} \mathrm{O}\right]<0.921\left(x_{1}\right.$ $\left.<2.27 \times 10^{-3}\right)$ and L-Phe ${ }_{+} \mathrm{H}_{2} \mathrm{O}$ is stable when $a\left[\mathrm{H}_{2} \mathrm{O}\right]>0.982\left(x_{1}>2.89 \times 10^{-3}\right)$ at the temperature range from $293.15 \mathrm{~K}$ to $308.15 \mathrm{~K}$. Based on the results mentioned above, an anhydrous L-Phe crystal can be obtained by adjusting $a\left[\mathrm{H}_{2} \mathrm{O}\right]$ during the temperature range studied. L-Phe can be gained by adjusting $a\left[\mathrm{H}_{2} \mathrm{O}\right]<0.921$. Meanwhile, the relationship between the transition water activity and temperature was investigated (Figure $4 a$ ). It can be seen that $\alpha$ w increased obviously with the increase of temperature, which can be described by Equation (17). Combining the obtained transition water activity, the solubility of metastable crystal form can be predicted by Equation (17) and Equation (7).

$$
a_{T}\left[H_{2} \mathrm{O}\right]=0.00673 T-1.0506 \mathrm{R}^{2}=0.99996
$$

In the solubility measurement experiment, the solubility of L-Phe ${ }_{+} \mathrm{H}_{2} \mathrm{O}$ at $302.15 \mathrm{~K}$ temperature in methanol-water solvents with the water activity of 0.84 was $3.19 \times 10^{-3}$, and the L-Phe solubility was $2.73 \times 10^{-3}$ calculated by Equation (7). The solubility of L-Phe ${ }_{+} \mathrm{H}_{2} \mathrm{O}$ in the same system was determined to be $2.38 \times 10^{-3}$ (see Table 1 ), which was consistent with the predicted results. 


\subsection{Transformation Kinetics}

The transformation behavior from anhydrous L-Phe to L-Phe ${ }_{+} \mathrm{H}_{2} \mathrm{O}$ at temperature $283.15 \mathrm{~K}$ and from L-Phe $\mathrm{H}_{2} \mathrm{O}$ to anhydrous L-Phe at temperature $323.15 \mathrm{~K}$ were carried out with the water activity of 0.77 and 0.84 . The transformation of crystal form plotted in Figure 5, showed that at temperature $283.15 \mathrm{~K}$, when the crystal transformation time reached $9 \mathrm{~h}$ (water activity equal to 0.84 as was shown in Figure $5 \mathrm{a}$ ) and $12.5 \mathrm{~h}$ (water activity equal to 0.77 as was shown in Figure $5 \mathrm{~b}$ ), the anhydrous L-Phe were substantially completely converted into L-Phe ${ }_{+} \mathrm{H}_{2} \mathrm{O}$. At temperature $283.15 \mathrm{~K}$, When the crystal form conversion time reached $3 \mathrm{~h}$ (water activity equal to 0.84 as was shown in Figure 5c) and $5.5 \mathrm{~h}$ (water activity equal to 0.77 as was shown in Figure $5 \mathrm{~d}$ ), the L-Phe $+\mathrm{H}_{2} \mathrm{O}$ were substantially completely converted into anhydrous L-Phe. The transformation behaviors indicated that the crystal form conversion of L-Phe can be inhibited with reducing water activity, which can be applied to control the production of anhydrous L-Phe.
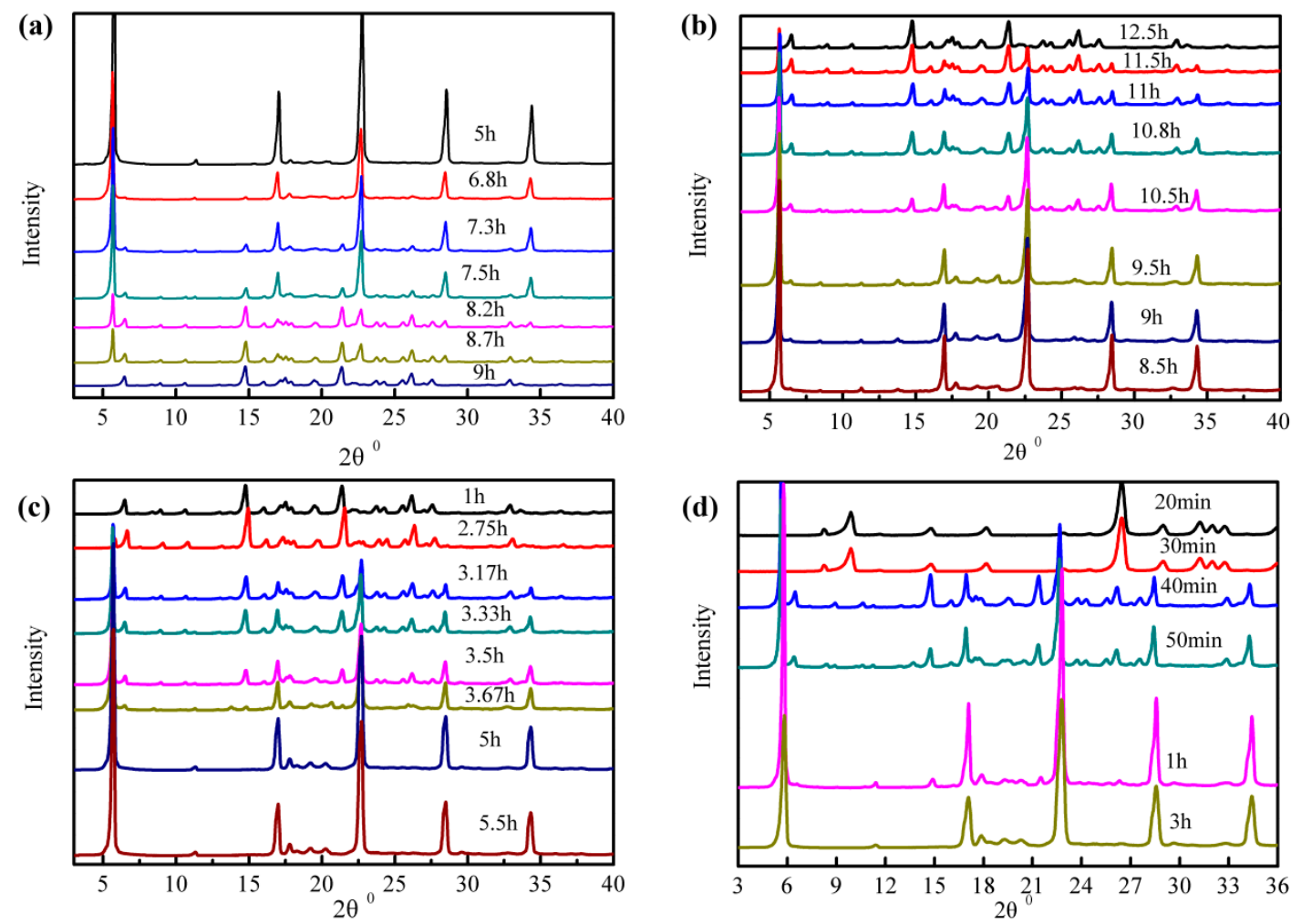

Figure 5. XRD patterns of L-Phe from anhydrate to monohydrate with water activity of (a) 0.84 and (b) 0.77 at temperature $283.15 \mathrm{~K}$; XRD patterns of L-Phe from monohydrate to anhydrate with water activity of (c) 0.84 (c) and (d) 0.77 at temperature $323.15 \mathrm{~K}$.

\subsection{Transformation Controlling by Additive}

The effects of additive concentration of L-His/L-Trp on transformation behavior of L-Phe from anhydrate/monohydrate to monohydrate/anhydrate were carried out in pure water at $283.15 \mathrm{~K} / 313.15$ K. The data were listed in Table 4 and calculated by Equation (16) were graphically shown in Figure 6. The inhibition behavior was represented by the Langmuir model (Figure 6). The values of fitting parameter $K, e$, and $R^{2}$ are shown in Table 5. It was concluded that the transformation behavior was markedly inhibited by the concentration of L-His/L-Trp additives at temperature $283.15 \mathrm{~K} / 313.15 \mathrm{~K}$. The relative transformation time $t_{0} / t$ from anhydrate to monohydrate at $283.15 \mathrm{~K}$ decreased steeply (roughly linearly) with the increase of L-Trp concentration. When the concentration of L-Trp is up to $0.7 \times 10^{-4} \mathrm{~mol} / \mathrm{mL}$, transformation behavior of L-Phe can be absolutely restrained, anhydrous L-Phe can be obtained at $283.15 \mathrm{~K}$ without transformation. Nevertheless, the L-Trp additive at $313.15 \mathrm{~K}$ and 
L-His additive at $283.15 \mathrm{~K} / 313.15 \mathrm{~K}$ all only can achieve partial inhibition, much attention should be paid to the transformation problem, when anhydrous L-Phe was crystallized from solution.

Table 4. Effect of additive concentration on the transformation behavior of L-Phenylalanine.

\begin{tabular}{|c|c|c|c|}
\hline $\begin{array}{l}\text { Additive Concentration } \\
\times 10^{5} /(\mathrm{mol} / \mathrm{ml})\end{array}$ & Transformation Time/h & $\begin{array}{l}\text { Additive Concentration } \\
\times 10^{5} /(\mathrm{mol} / \mathrm{ml})\end{array}$ & Transformation Time/h \\
\hline \multicolumn{4}{|c|}{ L-His } \\
\hline \multicolumn{2}{|c|}{$283.15 \mathrm{~K}$} & \multicolumn{2}{|c|}{$313.15 \mathrm{~K}$} \\
\hline 0 & 4 & 0 & 9 \\
\hline 0.41 & 5.42 & 0.48 & 23.17 \\
\hline 0.82 & 6.50 & 0.85 & 25 \\
\hline 1.63 & 7.33 & 1.21 & 29.17 \\
\hline 2.43 & 7.83 & 1.63 & 32 \\
\hline 3.25 & 8.33 & 2.11 & 40 \\
\hline 4.27 & 8.50 & 2.44 & 41.83 \\
\hline \multicolumn{4}{|c|}{ L-Trp } \\
\hline \multicolumn{2}{|c|}{$283.15 \mathrm{~K}$} & \multicolumn{2}{|c|}{$313.15 \mathrm{~K}$} \\
\hline 0 & 4 & 0 & 9 \\
\hline 0.31 & 7.50 & 0.38 & 18 \\
\hline 0.67 & 10.5 & 0.76 & 22.2 \\
\hline 0.93 & 14 & 1.30 & 24.17 \\
\hline 1.24 & 23 & 1.88 & 25.5 \\
\hline 1.54 & 26.17 & 2.56 & 27 \\
\hline 1.83 & 29.83 & 3.14 & 28 \\
\hline 2.51 & 36.17 & 3.71 & 28.33 \\
\hline
\end{tabular}
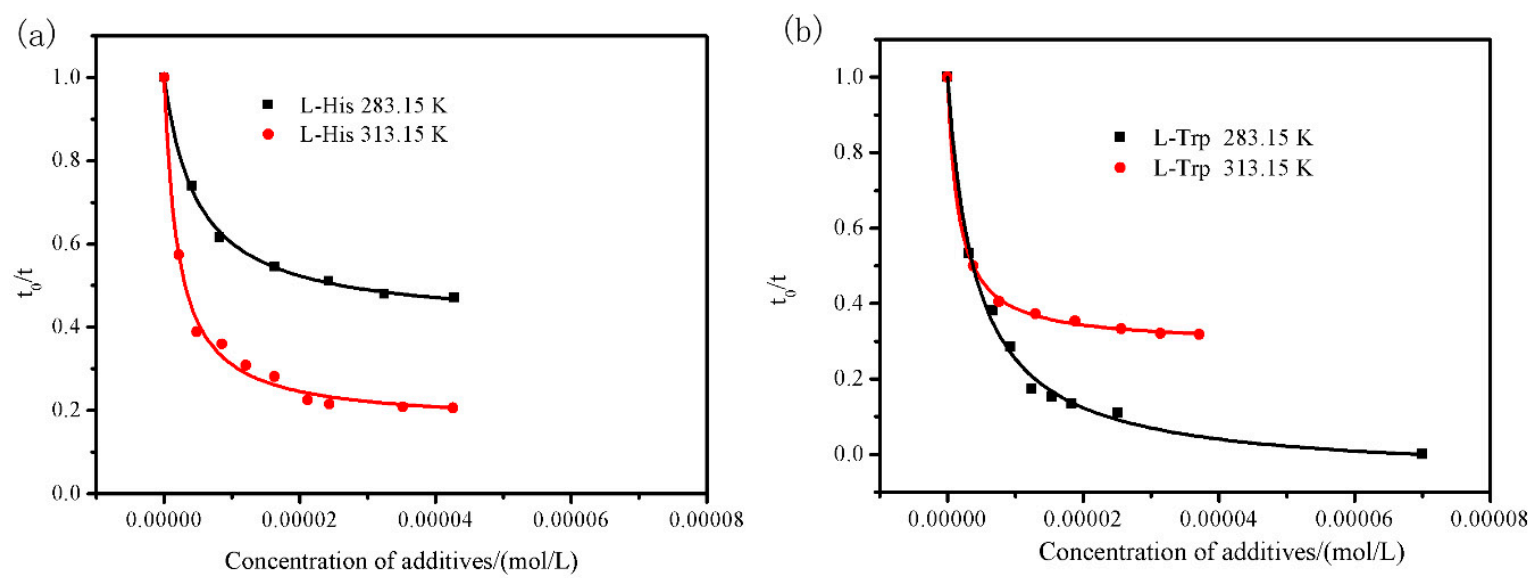

Figure 6. Fitting of the L-Phe transformation behavior data fitting in the presence of additive (a) L-His and (b) L-Trp at temperature $283.15 \mathrm{~K}$ and $313.15 \mathrm{~K}$ in pure water using the Langmuir model.

Table 5. The parameters of the Langmuir model.

\begin{tabular}{cccccccc}
\hline $\begin{array}{c}\text { Additive } \\
\text { Type }\end{array}$ & Temperature & $\begin{array}{c}\text { Transformation } \\
\text { Behavior }\end{array}$ & $\boldsymbol{K}$ & $\boldsymbol{e}$ & $\boldsymbol{R}^{\mathbf{2}}$ & $\begin{array}{c}\text { Additive } \\
\text { Concentration/(mol/ml) }\end{array}$ & Results \\
\hline L-Trp & $283.15 \mathrm{~K}$ & from A to M & $2.38 \times 10^{5}$ & 1.06 & 0.994 & $7.00 \times 10^{-5}$ & $\begin{array}{c}\text { Fully } \\
\text { inhibited } \\
\text { partially } \\
\text { inhibited }\end{array}$ \\
\hline L-His & $313.15 \mathrm{~K}$ & from M to A & $6.34 \times 10^{5}$ & 0.71 & 0.999 & 0.998 & $\begin{array}{c}\text { partially } \\
\text { inhibited } \\
\text { partially } \\
\text { inhibited }\end{array}$ \\
\hline
\end{tabular}




\section{Conclusions}

In this work, the solubility of L-Phe in water-methanol solvent mixtures with temperatures ranging from $293.15 \mathrm{~K}$ to $322.15 \mathrm{~K}$ in different water activities were increased with temperature and water activity and were correlated by the modified Apelblat equation and $\lambda \mathrm{h}$ equation. Meanwhile, the transition water activity at $293.15 \mathrm{~K}, 297.15 \mathrm{~K}$ and $302.15 \mathrm{~K}$ were measured and were $0.921,0.948$ and 0.982 respectively, which increased with temperature, obtaining the ternary phase diagram of methanol/L-Phe/water at that temperature. Results showed that anhydrous L-Phe could be produced by reducing the water activity in the system. Furthermore, the results of the transformation behavior of L-Phe showed that anhydrous L-Phe was substantially completely converted into L-Phe $+\mathrm{H}_{2} \mathrm{O}$ when the crystal form conversion time reached $9 \mathrm{~h}$ (water activity equal to 0.84 ) and $12.5 \mathrm{~h}$ (water activity equal to 0.77 ) at temperature $283.15 \mathrm{~K}$, and L-Phe ${ }_{+} \mathrm{H}_{2} \mathrm{O}$ was substantially completely converted into anhydrous L-Phe when crystal form conversion time reached $3 \mathrm{~h}$ (water activity equal to 0.84 ) and $5.5 \mathrm{~h}$ (water activity equal to 0.77 ) at temperature $323.15 \mathrm{~K}$. That is, transformation behavior can be inhibited by decreased water activity. Finally, the transformation behaviors of L-Phe from anhydrate/monohydrate to monohydrate/anhydrate in water with additives L-Trp/L-His acid were also investigated. The addition of L-Trp or L-His acid significantly impacted the transformation rate. When the concentration of L-Trp acid is larger than $0.7 \times 10^{-4} \mathrm{~mol} / \mathrm{mL}$, the transformation behavior of L-Phe can be completely suppressed, and yet the transformation behavior only partly was inhibited with the addition of L-Trp at $313.15 \mathrm{~K}$ and L-His at $283.15 \mathrm{~K} / 313.15 \mathrm{~K}$.

In this paper, the thermodynamic and kinetic properties of L-Phe were measured, which made it possible to change the solubility and crystallizing time according to adjust water activity, thereby further realizing the regulation of L-Phe from the perspective of water activity. At the same time, the production of L-Phe anhydrate from the additive aspect was realized by investigating the effects of additives on the transformation behavior of the L-Phe crystal form.

Author Contributions: Conceptualization, J.Z.; methodology, J.Z., W.K., and X.C.; formal analysis, X.C.; investigation, X.C.; resources, S.J.; data curation, X.X.; writing-original draft preparation, X.C.; writing-review and editing, J.Z., Y.B., A.L. and P.L. All authors have read and agreed to the published version of the manuscript.

Funding: This research was funded by the National Natural Science Foundation of China, grant number 21606056, the Guangxi Natural Science Foundation of China, grant number 2017GXNSFAA198091, the Guangxi Biological Polysaccharide Separation, Purification and Modification Research Platform, grant number GKZY18076005, the Xiangsihu Young Scholars Innovative Research Team of Guangxi University For Nationalities, grant number 2016, and the Postgraduate Research Innovation Project of Guangxi University of Nationalities, grant number gxun-chxzb2018001 (gxun-chxps201817).

Acknowledgments: In this section you can acknowledge any support given which is not covered by the author contribution or funding sections. This may include administrative and technical support, or donations in kind (e.g., materials used for experiments).

Conflicts of Interest: The authors declare no conflict of interest.

\section{References}

1. Bechtloff, B.; Nordhoff, S.; Ulrich, J. Pseudopolymorphs in industrial use. Cryst. Research. Technol. 2001, 36, 1315-1328. [CrossRef]

2. Brittain, H.G. Polymorphism and solvatomorphism 2010. J. Pharm. Sci. 2012, 101, 464-484. [CrossRef]

3. Vippagunta, S.R.; Brittain, H.G.; Grant, D.J. Crystalline solids. Adv. Drug Deliv. Rev. 2001, 48, 3-26. [CrossRef]

4. Tian, F.; Qu, H.; Zimmermann, A.; Munk, T.; Jørgensen, A.C.; Rantanen, J. Factors affecting crystallization of hydrates. J. Pharm. Pharmacol. 2010, 62, 1534-1546. [CrossRef]

5. Healy, A.M.; Worku, Z.A.; Kumar, D.; Madi, A.M. Pharmaceutical solvates, hydrates and amorphous forms: A special emphasis on cocrystals. Adv. Drug Deliv. Rev. 2017, 117, 25-46. [CrossRef]

6. Neglur, R.; Hosten, E.; Aucamp, M.; Liebenberg, W.; Grooff, D. Water and the relationship to the crystal structure stability of azithromycin. J. Therm. Anal. Calorim 2018, 132, 373-384. [CrossRef]

7. Zhu, H.J.; Yuen, C.M.; Grant, D.J.W. Influence of water activity in organic solvent plus water mixtures on the nature of the crystallizing drug phase. 1. Theophylline. Int. J. Pharm. 1996, 135, 151-160. [CrossRef] 
8. Li, Y.; Chow, P.S.; Tan, R.B.H. Effect of Water Activity on the Transformation between Hydrate and Anhydrate of Carbamazepine. Org. Process Res. Dev. 2008, 12, 264-270. [CrossRef]

9. Shefter, E.; Higuchi, T. Dissolution Behavior of Crystalline Solvated and nonsolvated forms of some pharmaceuticals. J. Pharm. Sci. 1963, 52, 781-791. [CrossRef]

10. Liu, C.; Dang, L.; Tong, Y.; Wei, H.Y. Influence of Polymorphs on the Transformation Water Activity of Theophylline. Ind. Eng. Chem. Res. 2013, 52, 14979-14983. [CrossRef]

11. Cuellar, M.C.; Herreilers, S.N.; Straathof, A.J.J.; Heijnen, J.J.; Wielen, L.A.M.V.D. Limits of operation for the integration of water removal by membranes and crystallization of L-phenylalanine. Ind. Eng. Chem. Res. 2009, 48, 1566-1573. [CrossRef]

12. Lu, J.; Li, Z.; Jiang, X.L. Solubility of L-phenylalanine in aqueous solutions. J. Chem. Eng. Jpn. 2010, 43, 810-813.

13. Lu, J.; Lin, Q.; Li, Z.; Rohani, S. Solubility of L-phenylalanine anhydrous and monohydrate forms: Experimental measurements and predictions. J. Chem. Eng. Data 2012, 57, 1492-1498. [CrossRef]

14. Lu, J.; Wang, J.; Li, Z.; Rohani, S. Characterization and pseudopolymorphism of L-phenylalanine anhydrous and monohydrate forms. Afr. J. Pharm. Pharmacol. 2012, 6, 269-277. [CrossRef]

15. Li, R.R.; Ye, S.F.; Chen, Y.F. Solubility of sulfachloropyridazine in pure and binary solvent mixtures and investigation of intermolecular interactions. J. Chem. Eng. Data 2018, 63, 2002-2008. [CrossRef]

16. Chao, Y.; Lo, T.; Luo, N. Selective production of L-aspartic acid and L-Phenylalanine by coupling reactions of aspartase and aminotransferase in Escherichia coli. Enzym. Microb. Technol. 2000, 27, 19-25. [CrossRef]

17. Xu, H.; Wei, P.; Zhou, H.; Fan, W.P.; Ouyang, P.K. Efficient production of Lphenylalanine catalyzed by a coupled enzymatic system of transaminase and aspartase. Enzym. Microb. Technol. 2003, 33, 537-543. [CrossRef]

18. Edahiro, J.; Nakamura, M.; Seki, M. Enhanced accumulation of anthocyanin in cultured strawberry cells by repetitive feeding of L-phenylalanine into the medium. J. Biosci. Bioeng. 2005, 99, 43-47. [CrossRef]

19. Wang, Z.Z.; Li, Y.; Fang, W.Z.; Wang, Q.; Xiao, H.Z.; Dang, L.P. Salting effects on the solubility and transformation kinetics of L-phenylalanine anhydrate/monohydrate in aqueous solutions. Ind. Eng. Chem. Res. 2014, 53, 521-529. [CrossRef]

20. Mohan, R.; Koo, K.K.; Strege, C.; Myerson, A.S. Effect of additives on the transformation behavior of L-phenylalanine in aqueous solution. Ind. Eng. Chem. Res. 2001, 40, 6111-6117. [CrossRef]

21. Zhang, J.Y.; Cao, X.X.; Ji, S.C.; Lan, P.; Liao, A.P. Solubility and transformation behavior of 1-phenylalanine anhydrate with amino acid additives. J. Therm. Anal. Calorim. 2018, 131, 1777-1781. [CrossRef]

22. Su, J.H.; Qian, C.; Luo, N.Z.; Xiang, X.G.; Xu, Y.M.; Chen, X.Z. Experimental measurement and modeling of the solubility of biotin in six pure solvents at temperatures from $298.15 \mathrm{~K}$ to $333.85 \mathrm{~K}$. J. Chem. Eng. Data 2014, 59, 3894-3899. [CrossRef]

23. Cashell, C.; Corcoran, D.; Hodnett, B.K. Effect of amino acid additives on the crystallization of L-glutamic acid crystal. Cryst. Growth Des. 2005, 5, 593-597. [CrossRef]

24. Manzurola, E.; Apelblat, A. Solubilities of 1-glutamic acid, 3-nitrobenzoic acid, p-toluic acid, calcium-1-lactate, calcium gluconate, magnesium-dl-aspartate, and magnesium-l-lactate in water. J. Chem. Thermodyn. 2002, 34, 1127-1136. [CrossRef]

25. Xie, Y.; Shi, H.W.; Du, C.B.; Cong, Y.; Zhao, H.K. Solubility determination and modeling for 4, 4-dihydroxydiphenyl sulfone in mixed solvents of (acetone, ethyl acetate, or acetonitrile)+ methanol and acetone + ethanol from (278.15 to 313.15) K. J. Chem. Eng. Data 2016, 61, 3519-3526. [CrossRef]

26. Yang, P.; Du, S.H.; Qin, Y.J.; Zhao, K.F.; Li, K.L.; Hou, B.H.; Gong, G.B. Determination and correlation of solubility and thermodynamic properties of pyraclostrobin in pure and binary solvents. J. Chem. Thermodyn. 2016, 101, 84-91. [CrossRef]

27. Yuan, F.H.; Wang, Y.L.; Xiao, L.P.; Huang, Q.Y.; Xu, J.C.; Jiang, C.; Hao, H.X. Solubility of cefoxitin acid in different solvent systems. J. Chem. Thermodyn. 2016, 103, 125-133. [CrossRef]

28. Zhu, M.H.; Zhang, H.H.; Zhang, K.K.; Yang, Y.Y.; Jiang, S.; Xu, S.J.; Liu, Y.M.; Gong, J.B. Measurement and correlation of solubility of boscalid with thermodynamic analysis in pure and binary solvents from $288.15 \mathrm{~K}$ to 313.15K. J. Chem. Thermodyn. 2017, 112, 178-187. [CrossRef]

29. Choi, W.S.; Kim, K.J. Solubility of Forms I and II of Clopidogrel Hydrogen Sulfate in Methanol and 2-Propanol Mixture. J. Chem. Eng. Data 2011, 56, 43-47. [CrossRef] 
30. Hong, M.; Xu, L.; Ren, G.; Chen, J.; Qi, M. Solubility of lansoprazole in different solvents. Fluid. Phase. Equilibr. 2012, 331, 18-25. [CrossRef]

31. Wang, X.F.; Dang, L.; Black, S.; Zhang, X.Y.; Wei, H.Y. How to Crystallize Anhydrous Racemic Tartaric Acid from an Ethanol-Water Solution. Ind. Eng. Chem. Res. 2012, 51, 2789-2796. [CrossRef]

32. Wilson, G.M. Vapor-liquid equilibrium. XI. A new expression for the excess free energy of mixing. J. Am. Chem. Soc. 1964, 86, 127-130. [CrossRef]

33. Gmehling, J.; Uo, W. Arlt: Vapor-Liquid Equilibrium Data Collection; Dechema: Frankfurt, Germany, 1981; Volume 1.

34. Kubota, N.; Mullin, J.W.A. kinetic model for crystal growth from aqueous solution in the presence of impurity. J. Cryst. Growth 1995, 152, 203-208. [CrossRef]

35. Davey, R.J.; Mullin, J.W. Growth of the 100 faces of ammonium dihydrogen phosphate crystals in the presence of ionic species. J. Cryst. Growth 1974, 26, 45-51. [CrossRef]

36. Martins, P.M.; Rocha, F.; Damas, A.M.; Rein, P. Unsteady-state inhibition of crystal growth caused by solution impurities. CrystEngComm 2011, 13, 1103-1110. [CrossRef]

(C) 2020 by the authors. Licensee MDPI, Basel, Switzerland. This article is an open access article distributed under the terms and conditions of the Creative Commons Attribution (CC BY) license (http://creativecommons.org/licenses/by/4.0/). 